\title{
PERLINDUNGAN DATA PRIBADI PENGGUNA SISTEM LAYANAN PERIZINAN BERUSAHA TERINTEGRASI SECARA ELEKTRONIK OSS 1.1 DAN OSS RBA (RISK BASIC APPROACH)
}

\author{
Twotik Lestariningtyas ${ }^{(1)}$ \\ Muhammad Roqib ${ }^{(2)}$ \\ ${ }^{(1)}$ Mahasiswa Fakultas Hukum Universitas Brawijaya \\ ${ }^{(2)}$ Dosen Fakultas Hukum Universitas Muhammadiyah Gresik \\ twotik.tyas@yahoo.com ${ }^{(1)}$ \\ muhammadroqib@umg.ac.id ${ }^{(2)}$
}

\begin{abstract}
ABSTRAK
Kemudahan berusaha merupakan aspek penting untuk terwujudnya peningkatan iklim investasi di Indonesia dalam upaya mewujudkan tujuan negara yaitu meningkatkan kesejahteraan masyarakat yang diimplementasikan dalam bentuk perizinan berusaha terintegrasi secara elektronik (OSS 1.1) sebagaimana dimaksud dalam Peraturan Pemerintah Nomor 24 Tahun 2018 dan disempurnakan dengan OSS RBA yang merupakan entitas dari Peraturan Pemerintah Nomor 5 Tahun 2021 tentang Perizinan Berusaha Berbasis Resiko. Metode yang dipergunakan dalam penelitian ini adalah penelitian hukum normatif (Normative legal research) dengan pendekatan statute approach yaitu mendasarkan pada telaah peraturan hukum terkait. Pengumpulan data dilakukan dengan studi dokumenter atau studi kepustakakan (library research) yang kemudian dilakukan analisa dengan metode kualitatif. Hasil dari pembahasan adalah terdapat beberapa perbedaan antara OSS 1.1 dan OSS RBA yaitu dari klasifikasi kegiatan usaha dimana OSS 1.1 mendasarkan pada jumlah modal dan KBLI sedangkan OSS RBA lebih menekankan pada pemilihan KBLI dan jumlah yang menetapkan tingkat resiko yang ditimbulkan. Baik dalam OSS 1.1 maupun OSS RBA belum mengatur secara jelas tentang perlindungan data pengguna sistem elektronik, namun demikian, perlindungan data mendasarkan pada ketentuan dalam Undang-Undang Informasi dan Transaksi Elektronik dalam bentuk penyelesaian sengketa secara administratif, penyelesaian sengketa secara perdata atau penyelesaian secara pidana.
\end{abstract}

Kata Kunci : Perlindungan data pribadi, sistem layanan perizinan berusaha terintegrasi secara elektronik, penyelesaian sengketa secara administratif, perdata, dan pidana. 


\section{A. PENDAHULUAN}

Kemudahan berusaha merupakan
aspek penting untuk terwujudnya
peningkatan iklim investasi di Indonesia
dalam upaya mewujudkan tujuan negara
yaitu meningkatkan kesejahteraan masyarakat. Salah satu misi dari Pemerintahan Presiden Jokowi pada misi ketiga yaitu memangkas hambatan investasi dan pada misi keempat yaitu reformasi birokrasi di mana salah satu poin pentingnya adalah percepatan pelayanan dan penerbitan perizinan. Beberapa hal yang menjadi catatan penghambat investasi di Indonesia di antaranya adalah adanya regulasi tumpang tindih, prosedur perizinan yang rumit, biaya mahal, rantai birokrasi yang berbelit-belit, dan disinyalir masih adanya pungutan liar yang terjadi dalam proses pengurusan perizinan.

Undang-Undang Nomor 11 Tahun 2020 tentang Cipta Kerja, bukanlah titik awal dimulainya konsep kemudahan berusaha dan pemangkasan birokrasi. Pada Tahun 2017 dengan Peraturan Presiden Nomor 91 Tahun 2017 tentang Percepatan Pelaksanaan Berusaha sehingga lahirlah Peraturan Pemerintah Nomor 24 Tahun 2018 tentang Pelayanan Perizinan Berusaha Terintegrasi Secara Elektronik, yang merupakan langkah nyata penerapan konsep kemudahan berusaha di Indonesia.
OSS / Sistem Pelayanan Perizinan

Berusaha Terintegrasi Secara Elektronik

"Kemudahan berusaha dalam

berbagai skala turut didorong

Pemerintah dengan reformasi

struktural, termasuk dengan reformasi

sistem perizinan. Penerapan

Pelayanan Terpadu Satu Pintu (PTSP)

dan Online Single Submission (OSS)

diharapkan efektif mengurangi

birokrasi dan mempermudah para

pelaku usaha. Pemerintah sudah

menjalankan Online Single

Submission (OSS) sebagai sistem yang mengintegrasikan seluruh pelayanan

perizinan berusaha yang menjadi

kewenangan Menteri/Pimpinan

Lembaga, Gubernur, atau

Bupati/Walikota yang dilakukan

secara elektronik. Melalui reformasi

sistem perizinan, kita mendorong

standardisasi menjadikan birokrasi perizinan di tingkat pusat dan daerah

lebih mudah, lebih cepat, dan juga lebih terintegrasi."

Joko Widodo, 16 Agustus 2018

Sumber : Laman Utama OSS 1.1

(www.oss.go.id)

Perizinan berusaha terintegrasi secara elektronik sebagaimana dimaksud dalam Peraturan Pemerintah Nomor 24 Tahun 2018 diimplementasikan dalam sistem/aplikasi pemerintah yaitu Online Single Submission atau yang kita kenal OSS. OSS merupakan perizinan yang diterbitkan oleh lembaga OSS untuk dan 
atas nama menteri, pimpinan lembaga, gubernur, atau bupati/wali kota melalui sistem elektronik yang terintegrasi. Sistem/aplikasi OSS ini yang kemudian kita kenal dengan OSS 1.1

Alur OSS 1.1

\section{LANGKAH MUDAH OSS}

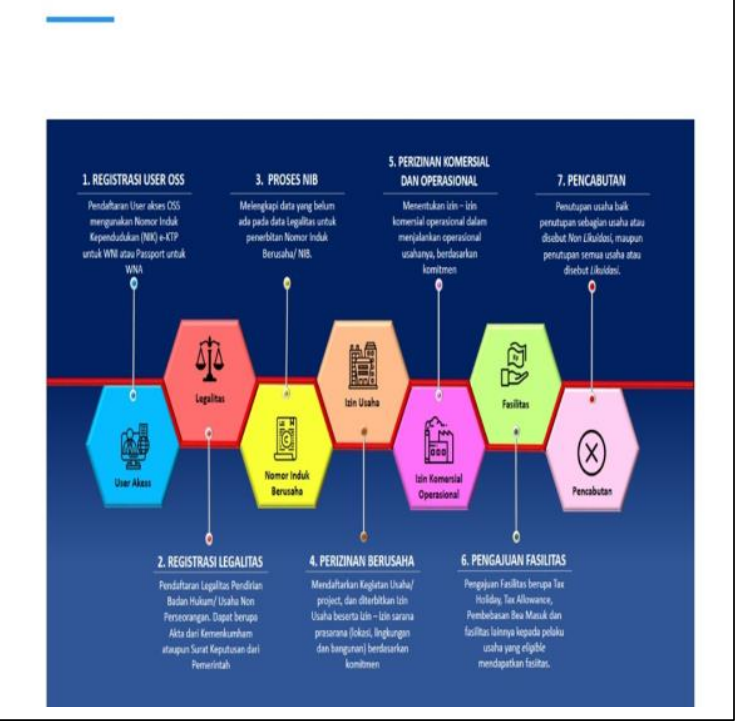

Kemudian pada tahun 2020 dengan berlakunya Undang-undang Nomor 11 Tahun 2020 tentang Cipta Kerja, sebagai peraturan pelaksanaannya terbit 49 Peraturan Pemerintah dan 4 Peraturan Presiden, salah satunya adalah Peraturan Pemerintah Nomor 5 Tahun 2021 tentang Perizinan Berusaha berbasis Resiko. Peraturan Pemerintah Nomor 5 tahun 2021 ini memunculkan sistem elektronik pelayanan perizinan yang baru yaitu OSS RBA (Risk Basic Approach) sebagai entitasnya.

Dalam sistem elektronik OSS (baik OSS 1.1 maupun OSS RBA) Pengguna sistem elektronik dalam hal ini adalah pemohon izin, atau pengusaha yang mendaftarkan kegitan berusaha melalui OSS. Sedangkan penyelenggara sistem elektronik adalah pemerintah.

Di dalam proses pendaftaran izin berusaha yang dimulai dengan pembuatan Nomor Induk Berusaha (NIB), pengguna harus memasukkan identitas diri yang wajib diinput, apabila tidak terisi maka pendaftaran tidak dapat berlanjut. Data pribadi yang dimaksud di antranya adalah identitas diri nama, NIK dan alamat email serta data-data pribadi lainnya. Yang nantinya data-data pribadi tersebut akan tersimpan dalam sistem OSS. Dalam pelaksanaannya beberapa pihak diberikan hak akses terhadap OSS, di antaranya adalah BKPM untuk Pemerintah Pusat dan DPMPTSP baik provinsi maupun kabupaten/kota untuk Pemerintah Daerah. Yang menjadi permasalahan adalah Bagimana perbandingan mekanisme perizinan berdasarkan sistem OSS 1.1 dan OSS RBA, dan bagaimana perlindungan hukum data pribadi pengguna sistem elektronik dalam OSS?

\section{B. PEMBAHASAN}

1. Bagaimana perbandingan mekanisme perizinan berdasarkan OSS 1.1 dan OSS RBA.

Secara umum perizinan dapat diartikan sebagai suatu pembolehan atau persetujuan dari penguasa yang 


\section{JURNAL JENDELA HUKUM}

ISSN Cetak E Online : 2355-5831/ 2355-9934

berwenang terhadap sesuatu yang sebelumnya dilarang, atau secara sederhana dapat diartikan bahwa izin adalah pembolehan atas sesuatu yang dilarang, dengan syarat dan ketentuan yang harus dipenuhi oleh pemohon izin itu sendiri.

Menurut para ahli perizinan adalah pemberian legalitas kepada seseorang atau pelaku usaha atau kegiatan tertentu, baik dalam bentuk izin maupun tanda daftar usaha. Izin ialah salah satu instrumen yang paling banyak digunakan dalam hukum administrasi, untuk mengemudikan tingkah laku para warga.

Pengertian izin di dalam kamus istilah hukum bahwa izin dijelaskan sebagai suatu perkenaan/izin dari pemerintah berdasarkan undang-undang atau peraturan pemerintah yang disyaratkan untuk perbuatan yang pada umumnya memerlukan pengawasan khusus, tetapi yang pada umumnya tidaklah dianggap sebagai hal-hal yang sama sekali tidak dikehendaki. Beberapa bentuk dari izin antara lain :

1. Suatu larangan

2. Suatu kewajiban

3. Suatu persetujuan

4. Merupakan ketentuan-ketentuan yang terkait dengan izin itu sendiri.

Dalam mekanisme perizinan tidak lepas dari yang namanya kewenangan, yaitu kewenangan dari pejabat yang dapat menerbitkan Perizinan.
Kewenangan menurut kamus besar bahasa Indonesia yaitu, berasal dari kata wenang adalah hak dan kekuasaan untuk melakukan sesuatu. Dalam Pasal 18 ayat (1) Undang Undang Dasar Negara Republik Indonesia Tahun 1945 (UUDNRI Th 1945) menegaskan "Negara Kesatuan Republik Indonesia dibagi atas daerah-daerah provinsi dan daerah provinsi itu dibagi atas kabupaten dan kota, yang tiap tiap provinsi, kabupaten dan kota itu mempunyai pemerintahan daerah, yang diatur dengan Undang-undang”.

Penggunaan istilah "dibagi atas" dimaksudkan untuk menegaskan bahwa hubungan antara Pemerintah Pusat dan Daerah bersifat hierarkis dan vertikal.

Menurut Bagir Manan (2000 : 1-2), wewenang dalam bahasa hukum tidak sama dengan kekuasaan (macht). Kekuasaan hanya menggambarkan hak untuk berbuat atau tidak berbuat. Dalam hukum, wewenang sekaligus berarti hak dan kewajiban (rechten en plichten). Dalam kaitan dengan otonomi daerah, hak mengandung pengertian kekuasaan untuk mengatur sendiri (zelfregelen) dan mengelola sendiri (zelfbesturen). Sedangkan kewajiban secara horisontal berarti kekuasaan untuk menyelenggarakan pemerintahan sebagaimana mestinya, dan vertikal berarti kekuasaan untuk menjalankan 
pemerintahan dalam satu tertib ikatan pemerintahan negara secara keseluruhan.

Kewenangan penerbitan perizinan berusaha menurut Peraturan Pemerintah Nomor 24 Tahun 2018 tentang Pelayanan Perizinan Berusaha Terintegrasi Secara Elektronik adalah Lembaga OSS atas nama menteri, pimpinan lembaga, gubernur, atau bupati/wali kota kepada Pelaku Usaha melalui sistem elektronik yang terintegrasi.

OSS merupakan terobosan Automatical Approval, yaitu tidak lagi memerlukan review atas dokumen yang disampaikan sepanjang memenuhi syarat administrasi yang ditetapkan. Dalam system OSS terdapat keseragaman Persyaratan sehingga dapat memberikan kepastian hukum atas perizinan itu sendiri.

Untuk memperbandingkan antara OSS 1.1 dan OSS RBA dapat diidentifikasi dalam matriks berikut :

\begin{tabular}{|c|c|c|c|}
\hline N0. & KOMPONEN & OSS 1.1 & OSS RBA \\
\hline 1. & Dasar Hukum & $\begin{array}{l}\text { PP Nomor } \\
24 \text { Tahun } \\
2018\end{array}$ & $\begin{array}{l}\text { PP Nomor } 5 \\
\text { Tahun } 2021\end{array}$ \\
\hline 2. & $\begin{array}{l}\text { Kewenangan } \\
\text { Penerbitan } \\
\text { Perizinan } \\
\text { Berusaha }\end{array}$ & $\begin{array}{l}\text { Lembaga } \\
\text { OSS }\end{array}$ & $\begin{array}{l}\text { Lembaga } \\
\text { OSS }\end{array}$ \\
\hline 2. & $\begin{array}{l}\text { Klasifikasi } \\
\text { Usaha }\end{array}$ & $\begin{array}{l}\text { Berdasar } \\
\text { Pada } \\
\text { Jumlah } \\
\text { Modal }\end{array}$ & $\begin{array}{l}\text { Berdasar } \\
\text { pada Resiko } \\
\text { dari } \\
\text { kegiatan } \\
\text { Usaha }\end{array}$ \\
\hline 3. & Skala Usaha & $\begin{array}{ll}\text { - } & \text { Mikro } \\
\text { - } & \text { Kecil, } \\
\text { - } & \text { Menen } \\
& \text { gah, } \\
\text { - } & \text { Besar }\end{array}$ & $\begin{array}{ll}- & \text { Resiko } \\
& \text { rendah } \\
- & \text { Resiko } \\
\text { Menen } \\
\text { gah } \\
\text { Rendah }\end{array}$ \\
\hline
\end{tabular}

\begin{tabular}{|c|c|c|c|}
\hline & & & $\begin{array}{ll}\text { - } & \text { Resiko } \\
\text { MEnen } \\
\text { gah } \\
\text { Tinggi } \\
\text { - } & \text { Resiko } \\
& \text { tinggi }\end{array}$ \\
\hline 4. & & $\begin{array}{l}\text { Untuk } \\
\text { Kegiatan } \\
\text { usaha yang } \\
\text { memilih } \\
\text { skala } \\
\text { Mikro } \\
\text { Legalitas } \\
\text { usaha } \\
\text { dengan } \\
\text { NIB dan } \\
\text { Izin Usaha. } \\
\text { Izin Usaha } \\
\text { ini telah } \\
\text { berlaku } \\
\text { efektif } \\
\text { tanpa } \\
\text { komitmen } \\
\text { ketika } \\
\text { memilih } \\
\text { mikro. }\end{array}$ & $\begin{array}{l}\text { Untuk } \\
\text { kegiatan } \\
\text { usaha } \\
\text { dengan } \\
\text { resiko } \\
\text { rendah, } \\
\text { legalitas } \\
\text { cukup } \\
\text { dengan } \\
\text { NIB. } \\
\text { Dalam NIB } \\
\text { ada } \\
\text { komponen } \\
\text { SPPL yang } \\
\text { merupakan } \\
\text { self declare }\end{array}$ \\
\hline 5 & $\begin{array}{l}\text { Penetapan } \\
\text { Pemenuhan } \\
\text { Komitmen }\end{array}$ & $\begin{array}{l}\text { Berdasar } \\
\text { Skala } \\
\text { Usaha dan } \\
\text { KBLI }\end{array}$ & $\begin{array}{l}\text { Berdasar } \\
\text { pada KBLI } \\
\text { dan Skala } \\
\text { Usaha }\end{array}$ \\
\hline 6. & Mekanisme & $\begin{array}{l}\text { System } \\
\text { Elektronik } \\
\text { Namun } \\
\text { pemenuhan } \\
\text { komitmen } \\
\text { belum } \\
\text { sepenuhnya } \\
\text { Elektronik }\end{array}$ & $\begin{array}{l}\text { System } \\
\text { Elektronik } \\
\text { Sampai } \\
\text { pada } \\
\text { pemenuhan } \\
\text { komitmen }\end{array}$ \\
\hline
\end{tabular}

Kelemahan dari sistem OSS 1.1 diantaranya adalah permohonan izin usaha mendasar pada skala usaha, dimana skala usaha ini ada 4 yaitu mikro, kecil, menengah dan skala besar. Dari semua skala ini memerlukan adanya izin usaha. Namun yang membedakan adalah ketika pemohon memilih skala mikro, maka izin 


\section{JURNAL JENDELA HUKUM}

ISSN Cetak E Online : 2355-5831/ 2355-9934

usaha akan serta merta berlaku efektif sehingga tidak memerlukan pemenuhan komitmen. Izin usaha skala mikro ini berlaku untuk semua sektor usaha, baik itu sektor industri sekalipun. Hal ini tentu akan berdampak pada lingkungan dan lain lain di masyarakat. Dan seringkali kegiatan berjalan diluar kendali pemerintah.

Beberapa kesamaan dari OSS 1.1 (Peraturan Pemerintah Nomor 24 Tahun 2018 tentang Pelayanan Perizinan Berusaha Terintegrasi Secara Elektronik) dan OSS RBA (Peraturan Pemerintah Nomor 5 Tahun 2021 tentang Perizinan berasis resiko) adalah sebagai berikut:

1. Menggunakan sistem elektronik dalam bentuk OSS.

2. Kewenangan penerbitan izin dari lembaga OSS bertindak untuk dan atas nama Menteri, Gubernur atau Bupati/Wali kota.

3. Mekanisme perizinan dapat dilakukan secara mandiri.

OSS RBA ini merupakan evaluasi atau perbaikan, sehingga sifatnya lebih pada penyempurnaa dari sistem OSS 1.1, pada saat OSS RBA ini berlaku maka OSS 1.1 dicabut dan dinyatakan tidak berlaku.

2. Perlindungan Hukum Data Pribadi Pengguna Sistem Elektronik Dalam OSS.

Di dalam Peraturan Pemerintah Nomor 24 Tahun 2018 tentang Pelayanan Perizinan Berusaha Terintegrasi Secara
Elektronik tidak menjelaskan dan tidak mengatur mengenai perlindungan data pribadi pengguna sistem elektronik dalam hal ini pemohon, demikian juga Peraturan Pemerintah Nomor 5 Tahun 2021 tentang Perizinan Berusaha Berbasis Resiko. Pada ketentuan Pasal 10 Peraturan Badan Koordinasi Penanaman Modal Republik Indonesia Nomor 3 Tahun 2021 tentang Sistem Perizinan Berusaha Berbasis Resiko Terintegrasi Secara Elektronik disebutkan bahwa Kementerian/Lembaga Terkait, pemerintah daerah provinsi, pemerintah daerah kabupaten/kota. Administrator KEK, dan badan pengusahaan KPBPB dalam menggunakan sistem OSS Wajib :

a. Menggunakan PIA sebagaimana pasal 8 ayat (2) huruf $b$.

b. Menjaga kerahasiaan data dan informasi pelaku usaha dalam OSS.

Namun demikian bukan berarti bahwa tidak ada perlindungan hukum atas data pribadi pengguna sistem elektronik OSS. Terhadap terjadinya pelanggaran dari penyelenggara sistem elektronik sehingga mengakibatkan kebocoran data atau kerugian terhadap pengguna sistem elektronik, dapat dilakukan upaya-upaya sebagai berikut : 


\section{a. Penyelesaian Secara Administratif}

1. Pasal 3 Peraturan Pemerintah No. 71 Tahun 2019 tentang Penyelenggaraan Sistem dan Transaksi Elektronik.

(1) Setiap Penyelenggara Sistem Elektronik harus menyelenggarakan Sistem Elektronik secara andal dan aman serta bertanggung jawab terhadap beroperasinya Sistem Elektronik sebagaimana mestinya.

(2) Penyelenggara Sistem Elektronik bertanggung jawab terhadap penyelenggaraan

Sistem

Elektroniknya.

2. Pasal 33 Peraturan Pemerintah Nomor 80 Tahun 2019 tentang Perdagangan Melalui Sistem Elektronik

(2) Dalam hal iklan elektronik disampaikan melalui sarana PPMSE dalam negeri dan/atau PPMSE luar negeri, PPMSE dalam negeri dan/atau PPMSE luar negeri wajib mematuhi ketentuan peraturan perundangundangan di bidang penyiaran, perlindungan atas privasi dan data pribadi, perlindungan Konsumen, dan tidak bertentangan dengan prinsip persaingan usaha yang sehat. serta juga terdapat ancaman sanksi administratif terhadap ketidakpatuhan atas aturan tersebut.
3. Pengaduan Kepada Menteri.

Pasal 26 Permenkominfo Nomor 20

Tahun 2016 tentang Perlindungan

Data pribadi Dalam Sistem

Elektronik.

Pemilik Data Pribadi berhak:

a. Atas kerahasiaan Data Pribadinya;

b. Mengajukan pengaduan dalam rangka penyelesaian sengketa Data Pribadi atas kegagalan perlindungan kerahasiaan Data Pribadinya oleh Penyelenggara Sistem Elektronik kepada Menteri;

Apabila upaya penyelesaian sengketa secara musyawarah atau melalui upaya penyelesaian alternatif lainnya belum mampu menyelesaikan sengketa, setiap pemilik data pribadi dan penyelenggara sistem elektronik dapat mengajukan gugatan perdata atas terjadinya kegagalan perlindungan kerahasiaan data pribadi.

\section{b. Penyelesaian Sengketa Secara Perdata}

Berdasarkan Pada Ketentuan Pasal 26 Undang-Undang Nomor 19 Tahun 2016 tentang Perubahan Atas Undang-Undang Nomor 11 Tahun 2008 tentang Informasi dan Transaksi Elektronik.

(1) Kecuali ditentukan lain oleh peraturan perundang-undangan, penggunaan setiap informasi melalui media 


\section{IURNAL JENDELA HUKUM}

ISSN Cetak E Online : 2355-5831/ 2355-9934

elektronik yang menyangkut data pribadi seseorang harus dilakukan atas persetujuan Orang yang bersangkutan.

(2) Setiap orang yang dilanggar haknya sebagaimana dimaksud pada ayat (1) dapat mengajukan gugatan atas kerugian yang ditimbulkan berdasarkan Undang-Undang ini.

Maka terkait perlindungan data pengguna sistem elektronik dapat melakukan gugatan secara perdata berdasar Pasal 1365 KUHPerdata sebagai Perbuatan Melawan Hukum (PMH).

- Mendasar pada ketentuan Pasal 3 Undang-Undang Nomor 11 Tahun 2008 Informasi dan Transaksi Elektronik Pemanfaatan Teknologi Informasi dan Transaksi Elektronik dilaksanakan berdasarkan asas kepastian hukum, manfaat, kehati-hatian, iktikad baik, dan kebebasan memilih teknologi atau netral teknologi. Maka Saudaara dapat melakukan gugatan perdata berdasarkan Pasal 1366 KUHPerdata atas dasar ketidakpatutan atau ketidakhati-hatian

\section{c. Pertanggungjawaban Pidana}

Kepada Penyelenggara sistem elektronik sebagaimana ketentuan dalam Undang-Undang Informasi dan Transaksi Elektronik yaitu Undang-Undang Nomor 11 Tahun 2008 sebagaimana telah diubah dengan Undang-Undang Nomor 19 Tahun 2016.
Pasal 30

(1) Setiap orang dengan sengaja dan tanpa hak atau melawan hukum mengakses Komputer dan/atau Elektronik milik Orang lain dengan cara apapun.

(2) Setiap orang dengan sengaja dan tanpa hak atau melawan hukum mengakses Komputer dan/atau Sistem Elektronik dengan cara apapun dengan tujuan untuk memperoleh Informasi Elektronik dan/atau Dokumen Elektronik.

(3) Setiap orang dengan sengaja dan tanpa hak atau melawan hukum mengakses Komputer dan/atau Sistem Elektronik dengan cara apapun dengan melanggar, menerobos, melampaui, atau menjebol sistem pengamanan.

Pasal 31

(1) Setiap orang dengan sengaja dan tanpa hak atau melawan hukum melakukan intersepsi atau penyadapan atas Informasi Elektronik dan/atau Dokumen Elektronik dalam suatu Komputer dan/atau Sistem Elektronik tertentu milik Orang lain.

(2) Setiap orang dengan sengaja dan tanpa hak atau melawan hukum melakukan intersepsi atas transmisi Informasi Elektronik dan/atau 
Dokumen Elektronik yang tidak bersifat publik dari, ke, dan di dalam suatu Komputer dan/atau Sistem Elektronik tertentu milik Orang lain, baik yang tidak menyebabkan perubahan apa pun maupun yang menyebabkan adanya perubahan, penghilangan, dan atau penghentian Informasi Elektronik dan/atau Dokumen Elektronik yang sedang ditransmisikan.

\section{PENUTUP}

1. Bahwa terdapat beberapa perbedaan antara OSS 1.1 yang mendasar pada Peraturan Pemerintah Nomor 24 TAhun 2018 tentang Pelayanan Perizinan Terintegrasi Secara Elektronik dan OSS RBA (Risk Basic Approach) yang mendasar pada Peraturan Pemerintah nomor 21 Tahun 2021 tentang Perizinan Berusaha Berbasis Resiko, dimana OSS 1.1 lebih mendasarkan kualifikasi kegiatan berusaha pada jumlah modal baru kemudian KBLI, sedangkan OSS RBA mengutamakan KBLI baru kemudian jumlah Modal untuk menentukan tingkat resiko terhadap kegiatan usaha yang dilakukan.

2. Di dalam OSS 1.1 dan OSS RBA belum mengatur secara pasti tentang perlindungan data pengguna sistem elektronik, namun bukan berarti tidak ada mekanisme perlindungan data pribadi dalam hal ini. Apabila terjadi kebocoran data atau pemanfaatan data oleh pihak yang tidak bertanggung jawab pengguna sistem elektronik dapat melakukan upaya hukum sebagaimana ketentuan Undang undang Informasi dan Transaksi Elektronik, yaitu upaya penyelesian sengketa secara administratif, upaya penyelesaian secara perdata atau upaya penyelesaian secara pidana.

\section{DAFTAR BACAAN}

\section{Buku}

Philipus M. Hadjon, Pengantar Hukum Perizinan, (Yuridika, Surabaya: 1993)

Ridwan HR, Hukum Administrasi Negara, (UII Press, Yogyakarta: 2003

Makalah ; Wewenang Provinsi, Kabupaten dan Kota Dalam Rangka Otonomi Daerah (Bandung: Seminar Nasional Fakultas Hukum UNPAD), hal 1-2.)

Pusat Studi Hukum Tata Negara, Fakultas Hukum UI, 2002

Fransiska Soejono1, Theresia Sunarni2, R. Kristoforus Jawa Bendi3, Maria Rosari Efila4, Savira Anthony1,

Rifqy Maulana, SH/ Dr. Jamhir, M.Ag Konsep Hukum Perizinan Dan PembangunanEmail: rifqymaulana@gmail.com

\section{Perundang-Undangan}

Undang-Undang Dasar 1945

Undang-Undang Nomor 39 Tahun 1999 tentang Hak Asasi Manusia

Undang-Undang nomor 11 Tahun 2008 tentang Informasi dan Transaksi Elektronik sebagaimana telah 
diubah dengan Undang-Undang Nomor 19 Tahun 2016

Undang-Undang Nomor 11 Tahun 2020 tentang Cipta Kerja

Peraturan pemerintah nomor 52 Tahun 2000 tentang Penyelenggaraan Telekomunikasi

Peraturan Pemerintah Nomor 82 Tahun 2012 tentang Penyelenggaraan Sistem dan Transaksi Elektronik

Peraturan Pemerintah Nomor 24 Tahun 2018 tentang Pelayanan Perizinan Berusaha Terintegrasi Secara Elektronik

Peraturan Pemerintah nomor 71 Tahun 2019 tentang Penyelenggaraan Sistem dan Transaksi Elektronik

Peraturan Pemerintah Nomor 80 Tahun 2019 tentang Perdagangan Melalui Sistem Elektronik

Peraturan Pemerintah Nomor 5 Tahun 2021 tentang Perizinan Berusaha Berbasis Resiko

Peraturan Pemerintah Nomor 6 Tahun 2021 tentang Perizinan Berusaha di Daerah

Permenkominfo Nomor 20 Tahun 2016 tentang Perlindungan Data pribadi Dalam Sistem Elektronik

Peraturan Badan Koordinasi Penanaman Modal RI nomor 3 Tahun 2021 tentang Sistem Perizinan Berusaha Berbasis Resiko Terintegrasi Secara Elektronik

\section{Jurnal}

Wenny Angeliana2 (2021) Pendampingan Usaha: Penggunaan One Single Submission Untuk Ijin Usaha Wikrama Parahita: Jurnal Pengabdian Masyarakat JPM Wikrama Parahita pISSN 2599-0020, e-ISSN 2599-0012

Ima Mayasari (2020) Kebijakan Reformasi Regulasi Melalui Implementasi Omnibus Law Di Indonesia Jurnal Rechts vinding Volume 9 Nomor 1 , April 2020

Melani1, Hari Sutra Disemadi2, Nyoman Serikat Putra Jaya (2020) Kebijakan Hukum Pidana Dibidang Transaksi Elektronik sebagai Tindak Pidana
Non-Konvensional Pandecta. Volume 15. Number 1. June 2020 Page 111-120 Fakultas Hukum Universitas Diponegoro DOI: http://dx.doi.org/10.15294/pandecta .v15i1.19469

Desi Arianing Arrum (2019) Kepastian Hukum Dalam Perizinan Berusaha Terintegrasi Secara Elektronik (Online Single Submission) di Indonesia Jurisdiction JuristDiction: Vol. 2 No. 5, September 2019.

Uchaimid Biridlo'i Robbyl dan Wiwin Tarwini (2019) Inovasi Pelayanan Perizinan Melalui Online Single Submission (Oss): Studi Pada Izin Usaha di Dinas Penanaman Modal Dan Pelayanan Terpadu Satu Pintu (DPMPTSP) Kabupaten Bekasi, Jurnal Ilmiah Administrasi Publik dan Pembangunan, Volume 10 Nomor 2 Tahun 2019.

RM. Hasbi Pratama Arya Agung (2021) Perlindungan Data Pribadi Dalam Proses Pengurusan Perizinan Perusahaan Berbasis Elektronik Online Single Submission (OSS) Jurnal Ilmiah Galuh Justisi Fakultas Hukum Universitas Galuh Volume 9 Nomor 1- Maret 2021.

\section{Laman}

http://kbbi.web.id/wenang, diakses pada tanggal 22 November 2017 